\title{
Peningkatan Kompetensi Manajerial Pengurus Organisasi Santri Pondok Pesantren Al-Falah Sumenep
}

\author{
${ }^{1}$ Abdul Azis, ${ }^{2}$ Andi Fepriyanto, ${ }^{3}$ Dian Helaprahara \\ STKIP PGRI Sumenep \\ 1azisyamhari@stkippgrisumenep.ac.id, ${ }^{2}$ andifepriyanto@stkippgrisumenep.ac.id, \\ dianhelaprahara@stkippgrisumenep.ac.id
}

\begin{abstract}
An organization is built to achieve goals through a series of managerial activities, the lack of management knowledge about good organizational management through effective and efficient management is one of the factors for not achieving organizational goals properly. This community service activity aims to improve the managerial competence of students organization of Al-Falah Islamic boarding school. This activity is carried out with a discovery learning approach followed by discussion and practice. The activity results showed that the participants' enthusiasm was relatively high with the number of questions asked and increased participants' knowledge in organizational management. At the time of mentoring, participants were able to apply their knowledge in managing the organization so that it could be concluded that the managerial competence of the board of student organization of Al-Falah Islamic boarding school had increased.
\end{abstract}

Keywords: Managerial Competence; Student Organization Member

\begin{abstract}
Abstrak
Sebuah organisasi dibangun dan dijalankan untuk mencapai tujuan melalui serangkaian aktifitas manajerial, minimnya pengetahuan pengurus tentang pengelolaan organisasi yang baik melalui managemen yang efektif dan efisien menjadi salah satu faktor ketidaktercapaian tujuan organisasi dengan baik. Kegiatan pengabdian masyarakat ini bertujuan meningkatkan kompetensi manajerial pengurus organisasi santri pondok pesantren Al-Falah Sumenep. Kegiatan ini dilaksanakan dengan pendekatan discovery learning kemudian dilanjutkan dengan diskusi dan praktik. Hasil kegiatan menunjukan bahwa antusiasme peserta cukup tinggi dengan banyaknya pertanyaan yang diajukan serta meningkatnya pengetahuan peserta dalam pengelolaan organisasi. Pada saat pendampingan, peserta sudah bisa mengaplikasikan pengetahuanya dalam mengelola organisasi sehingga dapat ditarik kesimpulan bahwa kompetensi manajerial pengurus organisasi santri Al-Falah meningkat.
\end{abstract}

Kata Kunci: Kompetensi Manajerial; Pengurus Organisasi Santri

Article Info:

https://doi.org/10.19105/pjce.v3i1.4652

Received 4 May 2021; Received in revised form 28 July 2021; Accepted 29 July 2021 
2684-9615/ (02021 Perdikan: Journal of Community Engagement. This is an open access article under the CC BY-NC 4.0 license (https://creativecommons.org/licenses/by-nc/4.0/)

\section{Pendahuluan}

Lembaga pendidikan Islam hadir dan muncul dengan berbagai model antara lain madrasah dan pondok pesantren. Menurut Saiful Sagala (2015), pondok pesantren berasal dari dua kata yaitu pondok yang berarti tempat tinggal atau asrama dan pesantren yangn berarti tempat santri mengaji agama Islam. Dari situ, pondok pesantren dapat dipahami sebagai tempat santri mengaji agama Islam dengan sistem asrama di bawah bimbingan kiai secara intensif dan berlangsung dalam waktu yang relative lama.

Pondok pesantren merupakan model lembaga pendidikan tertua di Indonesia karena keberadaannya sudah ada sejak zaman sebelum kemerdekaan Indonesia. Menurut Nuriyatun Nizah (2016), eksistensi pondok pesantren mulai muncul sekitar abad ke 20. Keberadaannya berawal dari keinginan atau motivasi umat Islam untuk menuntut ilmu/ thalbul ilmi sehingga menjadikan surau sebagai tempat menuntut ilmu di samping juga sebagai tempat ibadah.

Pada mulanya, pelaksanaan pendidikan agama Islam di pondok pesantren dilasanakan dengan model lesehan. Kemudian seiring dengan perkembangan zaman, pengelolaan pondok pesantren juga mengalami perkembangan dengan menerapkan model klasikal di mana pembelajaran dilaksanakan di dalam kelas dengan dilengkapi sarana dan prasarana penunjang seperti meja, bangku, papan tulis dan lainnya.

Kiai menjadi simbol dari sebuah pesantren. Kemajuan dan perkembangan pesantren sangat tergantung pada kemampuan dan karisma sosok kiai. Hal ini disebabkan oleh dua hal, yaitu bahwa kepemimpinan di pesantren bersifat individu dan tersentral pada sosok kiai (Ihsan \& Umar, 2020; Ramadhan, Faisol, \& Hakim, 2021; Yusuf \& Taufiq, 2020) serta keberadaan pesantren sebagai millik perseorangan atau keluarga dan bukan milik kelompok (Masyhud \& Khusnurdilo, 2004).

Menurut Muhammad Isnaini (2010), salah satu tipe atau gaya kepemimpinan di pesantren adalah karismatik. Seorang kiai dijadikan pemimpin karena memiliki karisma serta pengetahuan di bidang agama yang mendalam. Gaya kepemimpinan karismatik kiai merupakan sebuah keniscayaan karena kiai menjadi tokoh sentral di pesantren. Namun demikian, gaya kepemimpinan ini kemudian bergeser menjadi gaya kepemimpinan kolektif dengan ditandai sebagian besar pesantren yang saat ini berada di bawah naungan yayasan. Salah satu sebabnya adalah karena pesantren sudah mampu mengembangkan lembaga dan membutuhkan bantuan orang lain untuk ikut terlibat dalam pengelolaan pesantren. 
Perubahan gaya kepemimpinan di pesantren tidak hanya terjadi di tingkat pimpinan, tetapi juga terjadi di tingkat santri. Santri diberi wadah untuk dapat mengurus kepentingannya sendiri secara bersama-sama dalam bentuk organisasi santri. Keterlibatan santri dalam pengelolaan pesantren menurut Maryam Huda, dkk (2018) dikarenakan oleh tiga hal yaitu pertama bahwa semakin bertambahnya populasi atau jumlah santri yang ada sehingga pengawasan yang dilakukan oleh kiai dirasa kurang maksimal. Dari situ, kiai melimpahkan kewenangan tersebut kepada asatiz yang sudah cukup lama mengajar kemudian para asatiz mengajak para santri senior untuk juga ikut terlibat dalam pengurusan pesantren, Keterlibatan ini diharapkan dapat mempermudah pengurusan dan pengawasan pesantren.

Faktor kedua adalah perlunya aturan-aturan yang dibuat di pesantren untuk disosialisasikan di kalangan santri agar tidak terlalu menimbulkan resistensi dalam pelaksanaannya. Untuk memudahkan hal ini, diperlukan media komunikasi yang baik dan keberadaan organisasi santri dapat menjadi media komunikasi antara santri dan pengelola pesantren. Faktor ketiga adalah kemajuan teknologi informasi yang tidak dapat dihindari dan menuntut pesantren untuk memanfaatkan perkembangan tersebut untuk kemajuan dan perkembangan pesantren sendiri.

Berdasarkan tiga faktor tersebut, keterlibatan santri dalam pengelolaan pesantren memungkinkan tercipta dan terlaksananya program-program pesantren yang sesuai dengan bakat dan minat santri. Pondok pesantren Al-Falah Sumenep dalam hal ini merupakan lembaga pendidikan pesantren yang menggabungkan dua kurikulum sekaligus yaitu kurikulum sebagaimana diatur oleh pemerintah dan kurikulum kepesantrenan yang disusun dan dirancang sendiri oleh pesantren. Sebagaimana pesantren lainnya, pesantren ini juga menerapkan sistem asrama sehingga kehidupan santri dapat terpantau oleh kiai selama 24 jam dan pembelajaran di pesantren ini terjadi sejak santri bangu hingga akan tidur kembali.

Pengelolaan pesantren ini berada di bawah tanggung jawab kia, akan tetapi dalam pelaksanaannya, kiai juga dibantu oleh asatiz atau guru yang sudah lama diam dan bermukim di pondok. Selain itu juga dibentuk kepengurusan di kalangan santri yang bertujuan untuk fungsi-fungsi pengelolaan di lingkaran internal santri sendiri.

Dalam hal ini, organisasi santri Al-Falah Sumenep adalah organisasi yang dibentuk dalam rangka menjalankan fungsi operasional dari seluruh kegiatan santri. Kepengurusan organisasi ini dipilih dari santri kelas $V$ dan dibantu oleh santri kelas IV atau setara dengan siswa kelas $X$ dan siswa kelas XI. Pemilihan kepengurusan dilakukan setiap tahun dan diawali dengan pemilihan ketua organisasi yang dilakukan oleh seluruh santri serta seluruh asatidz meski keputusan akhir dan penentuan tetap berada 
di tangan pimpinan pondok. Karena itu, pemilik suara terbanyak tidak mesti menjadi ketua organisasi.

Setelah ketua organisasi dan wakil ketua terpilih, selanjutnya tim formatur akan membentuk struktur organisasi. Tim formatur ini terdiri dari ketua dan wakil ketua organisasi terpilih dan ketua dan wakil ketua organisasi demisionir serta majelis pembimbing organisasi. Hasil susunan kepengurusan yang telah dibentuk oleh tim formatur kemudian diajukan kepada pimpinan pondok pesantren untuk mendapatkan masukan dan restu.

Kegiatan dalam organisasi ini meliputi pengaturan seluruh kegiatan santri baik yang bersifat akademik maupun non akademik. Oleh sebab itu, dibentuk pula bagian-bagian atau unut-unit yang bertanggungjawab kepada ketua organisasi. Bagian-bagian tersebut meliputi bagian keamanan dan peribadatan, bagian pengajaran, bagian bahasa, bagian keterampilan dan kesenian, bagian kesehatan, bagian listrik dan air, bagian koperasi santri dal lain sebaginya.

Hasil wawancara terbatas dengan salah satu anggota majlis pembina organisasi mengungkapkan bahwa sebagian besar pengurus belum memilliki kemampuan manajerial yang baik. Karena itu, selama ini meraka melaksanakan kegiatan dengan hanya meneruskan kegiatan sebelumnya tanpa perencanaan yang jelas serta proses evaluasi yang cenderung berbasis formalitas saja. Hal ini disebabkan minimnya pengetahuan yang dimiliki pengurus terkait dengan proses dan mekanisme pengelolaan organisasi yang baik. Berdasarkan ini, dipandang perlu untuk memberikan pengetahuan kepada para pengurus tentang pengelolaan organisasi.

Ini utamanya ditujukan untuk meningkatkan kompetensi pengurus organisasi santri Al-Falah Sumenep terutama kompetensi manajerial melalui kegiatan pelatihan.

\section{Metode}

Metode pelaksanaan kegiatan pengabdian masyarakat ini terdiri dari tiga tahap yaitu tahap perencanaan, pelaksanaan dan terakhir adalah tahap evaluasi. Kagiatan pada tahap pelaksanaan melliputi analisis masalah pada pada kelompok sasaran dan diikuti dengan penentuan kegiatan sebagai upaya menyelesaikan masalah yang ada serta pengurusan izin kegiatan kepada pihak terkait.

Setelah program kegiatan ditentukan, langkah selanjutnya adalah pelaksanaan program kegiatan. Program ini laksanakan selama 2 (dua) hari dengan jadwal sebagai berikut:

Tabel 1. Jadwal Kegiatan Peningkatan Kompetensi Manajerial Pengurus Organisasi Santri Pondok Pesantren Al-Falah Sumenep.

\begin{tabular}{llcl}
\hline Hari Pertama & & \\
\hline No & Kegiatan & Waktu & Penanggungjawab \\
\hline 1 & Registrasi peserta & $07.00-07.30$ & Panitia \\
\hline
\end{tabular}




\begin{tabular}{llll}
\hline 2 & $\begin{array}{l}\text { Pembukaan oleh pimpinan } \\
\text { Pondok Pesantren Al-Falah } \\
\text { Sumenep }\end{array}$ & $07.30-08.30$ & Pimpinan Pondok \\
3 & $\begin{array}{l}\text { Pemaparan Materi 1: } \\
\text { Konsep dan Fungsi } \\
\text { Manajemen dalam }\end{array}$ & $09.00-10.30$ & Moderator \\
$\quad \begin{array}{lll}\text { Organisasi } \\
4\end{array}$ & $10.30-11.00$ & Moderator \\
\hline Tanya Jawab (diskusi) & Kedua & $07.00-08.30$ & Moderator \\
\hline 5 & $\begin{array}{l}\text { Pemaparan Materi 2: } \\
\text { Perencanaan Program }\end{array}$ & $08.30-09.00$ & Moderator \\
6 & $\begin{array}{l}\text { Kegiatan } \\
\text { Tlllanya Jawab (diskusi) }\end{array}$ & $09.00-10.30$ & Moderator \\
7 & $\begin{array}{l}\text { Pemaparan Materi 3: } \\
\text { Pelaksanaan Program }\end{array}$ & & \\
8 & $\begin{array}{l}\text { Kegiatan } \\
\text { Tanya Jawab (diskusi) }\end{array}$ & $10.30-11.00$ & Moderator \\
9 & $\begin{array}{l}\text { Pemaparan Materi 4: } \\
\text { Evaluasi Program Kegiatan }\end{array}$ & $13.00-14.30$ & Moderator \\
10 & Tanya Jawab (diskusi) & $14.30-15.00$ & Moderator \\
\hline
\end{tabular}

Setelah pelaksanaan program kegiatan, dilakukan evaluasi untuk memastikan ketercapaian tujuan dari kegiatan ini. Evaluasi dilakukan dengan pendekatan non-partisipatif selama satu bulan dengan melihat kinerja pengurus dalam menjalankan kegiatan organisasi.

\section{Hasil dan Pembahasan}

\section{a. Hasil}

Kegiatan peningkatan kompetensi manajerial pengurus organisasi santri Al-Falah Sumenep dilaksanakan selama dua hari kemudian dilanjutkan dengan pendampingan kegiatan organisasi selama satu bulan. Peserta dari kegiatan ini berjumlah 32 orang yang terdiri dari ketua organisasi serta ketua bagian-bagian yang ada di dalam organisasi beserta stafnya. Kegiatan ini dibuka langsung oleh pimpinan pondok pesantren Al-Falah Sumenep. Dalam sambutannya, beliau mengatakan bahwa kegiatan ini diharapkan dapat memberi manfaat lebih terutama dalam memajukan organisasi. Selain itu, beliau juga berharap pesantren Al-Falah Sumenep bisa menjadi mitra bagi kegiatan-kegiatan yang dilaksanakan oleh perguruan tinggi.

Sebelum materi pelatihan diberikan, terlebih dahulu dilakukan tes awal (pretest) untuk mengetahui pemahaman peserta terkait bagaimana menjalankan organisasi dengan baik. Hasil pretest menunjukkan bahwa pemahaman peserta masih tergolong kurang karena selama ini pengurus 
hanya menjalankan apa yang pernah dilakukan oleh pengurus yang lama tanpa ada inovasi atau perbaikan.

Setelah dilakukan pretest, selanjutnya adalah penyampaian materi tentang manajemen organisasi yang meliputi konsep dasar manajemen dalam organisasi serta fungsi-fungsi manajemen (perencanaan, pelaksanaan dan evaluasi). Pemberian materi ini dilaksanakan dengan strategi discovery learning. Strategi ini dipilih karena peserta pelatihan merupakan santri yang sudah memiliki pengalaman dari apa yang pernah mereka lihat, mereka dengar ataupun yang pernah mereka lakukan. Sedangkan metode yang digunakan adalah diskusi dan praktik.

Antusiasme peserta terbilang cukup tinggi dalam mengikuti rangkaian kegiatan. Ini terlihat dari banyaknya pertanyaan yang diajukan selama kegiatan berlangsung sehingga beberapa sesi mengalami kekurangan waktu. Setelah materi disampaikan, selanjutnya seluruh peserta dibagi ke dalam beberapa kelompok untuk melakukan diskusi pendalaman materi dan diikuti dengan praktik dan pada masing-masing kelompok dengan satu orang pendamping yang bertugas memastikan proses diskusi berjalan dengan baik.

Tabel 2. Rekapitulasi Hasil Pretest dan Postest

\begin{tabular}{llll}
\hline Variabel & Pre test & Post test & Peningkatan \\
\hline Perencanaan & 40 & 77 & 37 \\
Pengorganisasian & 43 & 75 & 32 \\
Kepemimpinan & 47 & 74 & 27 \\
Motivasi & 46 & 75 & 29 \\
Evaluasi & 48 & 79 & 31 \\
\hline TOTAL & $44,8 \%$ & $76 \%$ & $31,2 \%$ \\
\hline
\end{tabular}

Tahap akhir dari kegiatan ini adalah dilakukan test akhir (post-test) untuk melihat peningkatan pengetahuan dari peserta kegiatan. Berdasarkan data tebel 2 maka dapat disimpulkan bahwa terdapat peningkatan pengetahuan yang cukup signifikan yaitu sebesar $31,2 \%$.

Setelah semua rangkaian kegiatan dilaksanakan, tim pengabdian kepada masyarakat melakukan monitoring dan pendampingan selama satu bulan setelah kegiatan untuk memastikan dan melihat pengaplikasian fungsi-fungsi manajemen dalam organisasi selain juga sebagai media konsultasi bagi pengurus organisasi santri Al-Falah Sumenep.

\section{b. Pembahasan}

Pondok pesantren adalah lembaga pendidikan Islam yang memiliki kontribusi besar terhadap bangsa Indonesia baik sebelum maupun setelah kemerdekaan. Keberadaan pondok pesantren telah diakui secara yuridis formal di dalam Undang-Undang nomor 20 Tahun 2003 tentang sistem Pendidikan Nasional sehingga berimplikasi terhadap keikutsertaan 
pesantren dalam mencapai tujuan pendidikan nasional. Oleh sebab itu, pesantren perlu dikelola secara profesional.

Manajemen, menurut Usman (2008: 4), berasal dari Bahasa Inggris yaitu to manage yang kemudian diserap ke dalam Bahasa Indonesia menjadi manajemen yang berarti mengatur atau mengelola. Sedangkan secara istilah, manajemen menurut Robbins \& De Cenzo (1999: 4) adalah the process of efficiently achieving the organization objectives with and through people. Manajemen dikatakan sebagai proses karena di dalamnya terdapat kegiatan atau aktivitas-aktivitas yanng saling berkaitan satu sama lain. Aktivitas-aktivitas tersebut meliputi perencanaan, pelaksanaan dan evaluasi.

Tahap pertama dari kegiatan manajemen adalah perencanaan. Perencanaan dapat dipahami sebagai aktivitas penentuan tujuan organisasi serta cara atau strategi yang akan digunakan untuk mencapai tujuan secara efektif dan efisien. Perencanaan sangatlah penting karena di samping menjadi landasan dan pedoman bagi organisasi untuk bergerak, ia juga meminimalisir kegagalan-kegagalan yang mungkin terjadi serta sebagai tolak ukur dari pencapaian tujuan.

Beberapa ahli seperti Wijaya dan Rifa'i (2016: 27) mengutip pendapat Mondy \& Premeaux (1995) yang menjelaskan bahwa "planning is the process of determining in advance what should be accomplished and how it should be realized'. Berdasarkan pendapat tersebut, perencanaan merupakan proses penentuan apa yang ingin dicapai serta bagaimana cara mencapainya. Sedangkan Terry seperti dikutip (Sukarna, 2011) berpendapat bahwa "planning is the selecting and relating of facts and the making and using of assumption regarding the future ini the visualization and formulation of proposed activities necessary to achieve desired results". Berdasarkan pendapat tersebut, terdapat tiga poin pokok dalam perencanaan yaitu mengumpulkan data kemudian dilakukan analisis faktafakta untuk kemudian disusun rencana yang konkrit.

Perencanaan merupakan proses menjawab apa yang akan dilakukan, siapa yang akan melakukan, kapan dan di mana akan dilakukan, dan bagaimana akan melakukan sesuatu. Untuk menjawab pertanyaanpertanyaan ini, perlu dilakukan analisis SWOT dalam rangka melihat kekuatan, kelemahan, hambatan dan peluang yang dimiliki organisasi sehingga keputusan yang diambil lebih realistis.

Tahap kedua dari kegiatan manajemen adalah pengorganisasian. Pengorganisasian berasal dari kata organisasi. Menurut Mondy \& Premeaux (1995), "an organization is two or more people working together in a coordinated manner to achieve group results. Sedangkan Reeser (1973) mengemukakan "as managerial function, organizing is defined as grouping work activities into departement, assigning authority and coordinating the activities of the different departements so that objectives are met and conflicts get minimized". Kesimpulan dari dua pendapat 
tersebut adalah bahwa di dalam organisasi, terdapat hal-hal berikut. Pertama, dua orang atau sekelompok orang. Kedua, pembagian kerja yang jelas. Ketiga, aktivitas kerjasama. Keempat, upaya untuk mencapai tujuan.

Aktivitas atau kegiatan dalam pengorganisasian adalah pembagian tugas antarpersonil dengan jelas sehingga tercipta hubungan yang baik di dalam. Pembagian tugas ini juga akan memungkinkan setiap orang dalam organisasi bekerja dengan maksimal sesuai dengan kompetensi yang dimiliki. Proses pengorganisasian yang baik terlihat dari jelasnya tugas dan tanggungjawab dari masing-masing individu sehingga memudahkan pimpinan melakukan komunikasi.

Menurut Ahmad Paturusi (2012), pengorganisasian dipahami sebagai terbaginya seluruh tugas organisasi ke dalam unit-unit yang telah dibentuk sesuai dengan kompetensi yang dimiliki personil. Tentunya, pembagian tersebut didasarkan dengan pertimbangan aspek profesionalisme.

Tahap ketiga dari proses manajemen adalah penggerakan (actuating) yang berarti usaha menggerakkan seluruh personil dalam organisasi sesuai dengan tugas dan tanggungjawab masing-masing untuk mencapai tujuan. Pada tahap ini, terdapat beberapa aktivitas yang ikut terlibat di dalamnya antara lain motivasi dan kepemimpinan.

Sebagian besar ahli memahami kepemimpinan sebagai kemampuan mempengaruhi orang lain untuk mencapai tujuan. Definisi ini mengandung beberapa pokok gagasan, di antaranya adalah bahwa kepemimpinan mengandung konsep pengaruh dalam artian bahwa pengikut memiliki ketaatan dan mengikuti perintah dari pemimpin. Selain itu, pengaruh tersebut dapat dilakukan dengan perintah, stimulus ataupun dengan persuasi.

Setiap pemimpin memiliki gaya masing-masing dalam memimpin organisasinya. Sedikitnya, terdapat dua gaya yang sering digunakan oleh seorang pemimpin, yaitu gaya otoriter dan demokratis. Gaya otoriter memiliki ciri-ciri task oriented, tidak memberi kesempatan kepada bawahan untuk memberikan saran dan masukan, dan posisi bawahan yang hanya melaksanakan segala perintah dari pemimpin. Sedangkan gaya demokratis lebih ke arah human oriented, melibatkan bawahan dalam pengambilan keputusan serta keterbukaan pemimpin terhadap kritik, saran serta masukan. Dari dua gaya kepemimpinan tersebut, gaya kepemimpinan situasional lebih sering digunakan. Gaya ini menggunakan gaya kepemimpinan otoriter dan demokratis sekaligus sesuai dengan situasi dan kondisi bawahan yang dpimpin.

Kepemimpinan yang efektif adalah ketika pemimpin mampu memotivasi bawahan untuk mengerahkan seluruh potensi yang dimiliki dalam rangka mencapai tujuan organisasi. Setiap individu di dalam organisasi serta organisasi itu sendiri tentunya memiliki kebutuhan secara bersamaan. Pimpinan harus dapat memastikan terpenuhinya kebutuhan tersebut, akan 
tetapi dalam waktu yang sama ia harus memiliki tolak ukur yang konkrit dan jelas sebagai landasan dalam pemberian hadiah/gaji. Ini berarti bahwa individu dalam organisasi harus berkomitmen untuk bekerja secara produktif membantu organisasi dalam mencapai/memenuhi tujuan-tujuan serta sasaran yang telah ditetapkan.

Dengan demikian, motivasi dapat dimaknai sebagai kesediaan individu mengerahkan segala upaya demi tercapainya tujuan organisasi. Definisi tersebut memuat 3 komponen utama yaitu: effort (usaha berintensitas tinggi, usaha keras yang berlandaskan willingness dan ability); organization goals (tujuan organisasi yang berfungsi menjadi pengarah usaha); serta needs (sesuatu yang menjadi tantangan motivasi dan akan memberikan rasa puas apabila terpenuhi).

Tahap terakhir dari kegiatan manajemen adalah evaluasi. Evaluasi adalah proses pengumpulan data atau informasi terkait dengan pelaksanaan suatu program atau kegiatan. Evaluasi bertujuan untuk melihat ketercapaian tujuan yang ingin dicapai serta hambatan atau kendala yang dihadapi selama pelaksanaan kegiatan. Evaluasi ini bisa dilakukan di akhir kegiatan ataupun di pertengahan/ketika kegiatan sedang berlangsung.

\section{Kesimpulan}

Berdasarkan paparan dari hasil pengabdian kepada masyarakat dengan judul Peningkatan Kompetensi Manajerial Pengurus Organisasi Santri Al-Falah Sumenep, dapat ditarik beberapa kesimpulan bahwa pelaksanaan kegiatan pengabdian masyarakat dengan tema peningkatan kompetensi manajerial pengurus organisasi santri Al-Falah berjalan dengan baik. Autusiasme peserta dalam mengikuti rangkaian kegiatan cukup tinggi. Terdapat pula peningkatan pengetahuan dan kompetensi manajerial dalam mengelola organisasi.

\section{Daftar Pustaka}

Huda, M. (2018). Manajemen Organisasi Santri dalam Mewujudkan Pesantren yang Lebih Baik. Tadbir: Jurnal Manajemen Dakwah, 3(2), 35-62.

Ihsan, \& Umar, A. (2020). Kiai as al-Qudwah al-Khasanah: The Role of Kiai in Shaping Religious Culture in Islamic Education Institution. Al-A'raf: Jurnal Pemikiran Islam dan Filsafat, 17(2), 329-346. https://doi.org/10.22515/ajpif.v17i2.2995

Isnaini, M. (2010). Dinamika Kepemimpinan Kolektif Pesantren sebagai Pusat Pendidikan Islam di Sumatera Selatan. Publikasi Penelitian Terapan dan Kebijakan, 4(2).

Khusnurdilo, M. S. M. D. M., \& Mahmud, M. S. (2004). Manajemen Pondok Pesantren. Jakarta: Diva Pustaka. 
Mondy, R. W., \& Premeaux, S. R. (1995). Management: Concepts, Practices, and Skills. New Jersey: Prentice Hall.

Nizah, N. (2016). Dinamika Madrasah Diniyah: Suatu Tinjauan Historis. Edukasia: Jurnal Penelitian Pendidikan Islam, 11(1), 181202.

Paturusi, A. (2012). Manajemen Pendidikan Jasmani dan Olahraga. Jakarta: Rineka Cipta.

Ramadhan, M. W., Faisol, A., \& Hakim, D. M. (2021). Peran Kiai sebagai Figur Sentral Pendidik dalam Mengembangkan Karakter Islam Santri Pondok Modern Darul Ma'rifat Kediri. Vicratina: Jurnal Pendidikan Islam, 6(1), 274-283.

Reeser, C. (1973). Management Function and Modern Concepts. Illions: Scotforesman and Company.

Robbins, S.P. \& De Cenzo, A.D. (1999). Human Resources Management. New York: John Willwy \& Sons, Inc.

Sagala, S. (2015). Manajemen dan Kepemimpinan Pendidikan Pondok Pesantren. Jurnal Tarbiyah, 22(2), 205-225.

Sukarna. (2011). Dasar-Dasar Manajemen. Bandung: Mandar Maju.

Usman, H. (2008). Manajemen Teori, Praktik, dan Riset Pendidikan. Jakarta: Bumi Aksara.

Wijaya, C., \& Rifa'i, M. (2016). Dasar-dasar Manajemen: Mengoptimalkan Pengelolaan Organisasi secara Efektif dan Efisien.

Yusuf, Moh. A., \& Taufiq, A. (2020). The Dynamic Views of Kiais in Response to the Government Regulations for the Development of Pesantren. QIJIS (Qudus International Journal of Islamic Studies), 8(1), 1-32. https://doi.org/10.21043/qijis.v8i1.6716 